\title{
Digital Humanities in Biblical Studies and Theology
}

Peter Phillips*, Kyle Schiefelbein-Guerrero, Jonas Kurlberg

Defining Digital Theology: Digital Humanities, Digital Religion and the Particular Work of the CODEC Research Centre and Network

https://doi.org/10.1515/opth-2019-0003

Received February 4, 2019; accepted March 21, 2019

\begin{abstract}
This article seeks to define Digital Theology, first by exploring the development of the CODEC Research Centre at Durham University - perhaps the only centre developed to explore Digital Theology. The aims of the centre and some of its projects are explored leading to a discussion of CODEC's place within Digital Humanities. The article concludes with a focus on different aspects and definitions of Digital Theology.
\end{abstract}

Keywords: Digital Humanities, Digital Theology, Theology, Computing for Humanities, digital culture, CODEC

\section{CODEC's practical fusion of Digital Humanities and Digital Theology}

The CODEC Research Centre for Digital Theology at the University of Durham formally came into existence in 2014, although the seeds had been sown in an earlier project proposal which brought together a small group of researchers at one of Durham's colleges, St John's, some five years earlier. Initially, it was our intention to explore three areas: biblical literacy, digital culture, and contemporary preaching. CODEC helped to develop a major national survey in biblical literacy in 2009, published research on preaching in the contemporary church, and began to explore the impact of digital culture on the training of Christian ministers and within the Church in general.

Within the first five years, CODEC developed a number of projects around each of these three areas. CODEC employed a number of post-doctoral researchers, several of whom had just finished their PhDs. These researchers worked with CODEC to write up the research but also to manage projects. As is to be expected, post-doctoral researchers are actually keen to develop their own research and publishing career in order to take up full-time/tenured positions elsewhere. This meant that at times CODEC's focus had become diverse, too diverse for some, but perhaps reflecting already a shift towards big tent Digital Humanities.

Early on, CODEC developed good relationships with international and national Bible Societies and began work with Biblica on "The State of Biblical Literacy in the UK" around 2013 and developed a research

\footnotetext{
*Corresponding author: Peter Phillips, Durham University, United Kingdom of Great Britain and Northern Ireland; E-mail: p.m.phillips@durham.ac.uk

Kyle Schiefelbein-Guerrero, Berkeley Graduate Union, United States of America

Jonas Kurlberg, Durham University, United Kingdom of Great Britain and Northern Ireland
} 
project on "Digital Millennials and the Bible" beginning in 2016. Moreover, a major UK funding body, the Jerusalem Trust, helped CODEC to develop the BigBible project around digital engagement with the Bible. The project has run successfully for over seven years. The Trust also approached CODEC in 2014 and invited a bid to develop an online portal for digital discipleship resources. CODEC was awarded significant funding to develop this portal and put in place the staffing for it. Indeed, over the next three years, CODEC worked with over 600 providers to develop a portal offering resources for discipleship which could be downloaded, mostly for free, and worked with a resource provider, 12 Baskets, to provide an electronic point of sale system. By the end of 2017, however, it became clear that the resource was not gaining the footfall needed and CODEC made the decision to close down the resource, writing up the research and moving further into research development and writing.

From 2015 onwards, CODEC moved more towards research outputs. As such, Peter Phillips, the director of CODEC, has continued to publish within the field of Johannine studies and literary theory while also now developing conference papers and articles around Digital Theology within the Digital Humanities. ${ }^{1}$ His current work is broadly based on what he calls the pixelated Bible or the mediated text. He regards his work as embedded within Digital Humanities research: a merger of biblical reception, visual culture studies, theology and sociology, with a good dose of technological improvisation. He has written papers on digital manuscripts for various conferences and on the issue of obsolescence of digital projects and the rise of the digital facsimile. But Phillips' work also has a focus on the interpretation of culture with recent articles on the depiction of biblical narratives in film and in the exploration of transhumanism and human identity in science fiction narratives such as Blade Runner 2049. Karen O'Donnell's research picked up similar themes on theological anthropology and human identity, as well as her core research on digital pedagogy, and is now developing a constructive theology for a digital age. ${ }^{2}$ In 2018, a major article exploring the state of biblical literacy within digital culture was published in Theology and in 2019, two books will be published - a joint volume with David Ford and Josh Mann on Digital Millennials and the Bible and a monograph on The Bible, Social Media and Digital Culture. Josh Mann published a quartet of articles around Digital Humanities and the Bible and digitality, and he is currently working on a monograph entitled Computing the Bible: A Brief History. ${ }^{3}$ Dr Bex Lewis developed an important study on the interface between digital culture and children, as well as developing important conversations around bible engagement in a digital environment. ${ }^{4}$ Marika Rose developed the Trove resource and published a number of articles around digital culture and preaching, as well as exploring identity and theological anthropology in a digital age. ${ }^{5}$ Tim Hutchings, on top of his own prodigious research in the field of Digital Religion, worked with CODEC to develop the peer-reviewed Journal for Religion, Media and Digital Culture, now hosted by Brill. ${ }^{6}$

In 2017, CODEC welcomed its first cohort of students on its new MA in Digital Theology, joining a small number of PhD students working with us in Durham as well as cross-supervision of students in Finland exploring theology and computer science. Teaching and training had always been a large part of what CODEC had done, and throughout the research centre's existence, we offered a one week intensive module called Medialit exploring Christian communication in digital culture.

1 See, for example, Phillips and Briggs, “The Bible as Augmented Reality”; Phillips, "A Responsive Chorus: The Samaritans of Sychar"; Phillips, "The Adulterous Woman: Nameless, Partnerless, Defenceless”; Phillips, Lewis, and Bruce, "Digital Communication, the Church and Mission"; Phillips, "Wesley's Parish and the Digital Age”; Phillips, "The Pixelated Text: Reading the Bible within Digital Culture”; Phillips, "The Power of Visual Culture and the Fragility of the Text."

2 See, for example, O’Donnell, "Performing the imago Dei: human enhancement, artificial intelligence and optative imagebearing”; O’Donnell, “Being Corporeal in Digital Spaces”; O’Donnell and Midson, eds., "Special Edition on Human Relationships and Digital Technologies”; O’Donnell, Digital Theology: Constructing Theology for a Digital Age.

3 See, for example, Mann, "The Hermeneutics of Digital Bibles”; Mann, "Augmented Reality, Virtual Reality, and Religion: Past, Present, and Future”; Mann, "Mobile Liturgy: Reflections on the Church of England's Suite of Digital Apps”; Mann, "How Technology Means: Texts, History, and Their Associated Technologies."

4 Lewis, Raising Children in the Digital Age.

5 See, for example, Rose, "Machines of loving grace: angels, cyborgs, and postsecular labour”; Rose, "It's Not the Money but the Love of Money That Is the Root of All Evil"

6 https://brill.com/view/journals/rmdc/rmdc-overview.xml. 


\section{Digital Humanities, interdisciplinarity and the "big tent" approach}

We have already mentioned the idea of "big tent" Digital Humanities - the broadest definition of Digital Humanities popularised after the international Digital Humanities conference in 2011 which explored this issue that had arisen in plenary conversations at the previous year's international meeting. ${ }^{7}$ Claire Warwick and others proposed a session outlining the argument for a "big tent" approach, drawing in both academic disciplines but also libraries, museums, archives, cultural heritage practice, and commercial information providers. This was a Digital Humanities writ large approach - a big tent welcoming all to work together across disciplines and institutions with the new centre at University College London operating as a kind of network or hub. However, the centre also provided specific research projects such as "Transcribe Bentham" - a tool to educate users about transcription and then to provide a crowd-sourced transcription of Jeremy Bentham's original letters.

The conversation focused on whether Digital Humanities was to be focused on the computational resourcing of humanities research ("more hack less yack") ${ }^{8}$ or on a much bigger fusion of humanities research areas alongside developing the humanities' computing and digital methodologies for humanities research. The members of the research hub, UCLDH, did not want to put up boundaries or to provide stringent definitions but rather to embrace a view of DH that is "crowd sourced, inclusive and ever growing": "We wish to open wide the doors of this amazingly diverse discipline to any and all of those who would like to take part." Others, even those later associated with UCLDH such as Melissa Terras, were uneasy with the concept of "big tent" Digital Humanities, picking up on the rather uncomfortable circus imagery and pointing instead to the core interdisciplinarity of all academic work in the contemporary era. Academics were no longer single subject specialist but must be diverse digital scholars. ${ }^{9}$

CODEC, in its own way, offers an analog of this debate within Theology and Religious Studies - a crossdisciplinary, open network of scholars working in and around the interface between theology and digital culture. It is a "big tent" approach which has drawn the ire of those who seem to prefer the traditionally siloed academic disciplines and rigid structures. CODEC's "big tent" approach is not without strong critics. But this, of course, is all part of the wider definitional war within Digital Humanities. ${ }^{10}$

In his collection of essays on Digital Humanities, David Berry argues that "across the university, the way in which we pursue research is changing, and digital technology is playing a significant part in that change. Indeed, it is becoming more and more evident that research is increasingly being mediated through digital technology." ${ }^{11}$ This impact is increasingly important across many disciplines and, picking up Kuhn's sense of paradigm shifts, Berry talks of a paradigm shift in academic research of all kinds. ${ }^{12}$ Indeed, in her own soft criticism of "big tent" Digital Humanities, Terras outlines how all research has become both interdisciplinary and digital for most people engaged in contemporary scholarship. No one does research like they used to. ${ }^{13}$

Such views were strongly resisted as simply "insurgent Humanities" by establishment figures such as Stanley Fish. ${ }^{14}$ Fish talks of "longform scholarship" or "linear scholarship," which takes much more time and seeks a much deeper resonance than he thinks the evanescent Digital Humanities are able to

7 Warwick et al., "UCLDH: Big Tent Digital Humanities in Practice.”

8 Meloni, "Reporting from 'Academic Summer Camp': The Digital Humanities Summer Institute,” cited in Warwick "UCLDH: Big Tent Digital Humanities in Practice”; see also Nowviskie, "On the origin of 'hack' and 'yack.”

9 Terras, "Peering Inside the Big Tent."

10 Liu, "The Meaning of the Digital Humanities."

11 Berry, "Introduction: Understanding the Digital Humanities," 1.

12 A common theme in the literature, for example: Berry, "Introduction," 9; Stommel, "Digital Humanities is about Breaking Stuff."

13 Terras, "Peering Inside," 264-266.

14 Fish, "The Digital Humanities and the Transcending of Mortality"; see also the exploration and critique of Heidegger's negativity towards technology in Iain Thomson's “Understanding Technology Ontotheologically, or: the Danger and Promise of Heidegger, an American Perspective.” 
achieve. Such models of scholarship fit into the distinctions between "close reading" (currently often best done by humans) and "distant reading" (often only possible by machine). Fish represents what Mikhail Epstein, from a computer science/educational theorist perspective, argues is the "main problem with the Humanities today," namely, "their self-enclosure in the past and their alienation from contemporary society." He argues that humanities scholars "are interested mostly in texts and their critical interpretations, and in hypercritical interpretations of interpretations." ${ }^{15}$ Of course, this is the caricature of contemporary humanities scholarship which Terras argues no longer applies to research in the digital era.

In the area of the Digital Humanities, Berry and others have argued that there were two main waves of transformation. ${ }^{16}$ The first wave focused on digitization projects, technological advance, and infrastructure reorganization. The second wave focused on the production, curation, and interaction with knowledge that is "born digital" and exists digitally. Leighton and Rees suggest that this second wave needs to be subdivided into 2a: the analysis of traditional categories of the humanities through digital technology, and then 2b: the creation of new concepts in the humanities involving the digital. But this is "big tent" Digital Humanities rather than "Computing for Humanities," which tends to be much more focussed on the technological side of things. In a recent article addressing Digital Humanities and Digital Theology, Clifford Anderson offers a much more limited definition: "My standard rubric is that the Digital Humanities applies computational methods to the analysis of classical problems in the Humanities." ${ }^{17}$ Professor Erkki Sutinen, head of Computer Science at the University of Turku in Finland, has promoted a co-design approach to Digital Theology, arguing that the most exciting results will probably arise not from a polarisation of methods but through the creative tension of bringing computing and theology together, perhaps through a co-design process between institutions which have the confidence to bring computer scientists and theologians/ humanities researchers together.

CODEC has advocated "big tent" Digital Theology within "big tent" Digital Humanities - the kind of seismic shift which Terras, Berry, and others have proposed. Along these lines, Epstein speaks of "Transformative Humanities" in terms first of preservation: "the need to preserve the beauty of common, 'irregular' language as distinct from the 'precise' languages of sciences and computers"; and then of transformation: "the developing of full human potential as it is increasingly explored and implemented by sciences and technology." Overall, he talks of the need for humanities that will "reaffirm the human measure of things - not simply to reaffect the enchantment of the world, but to rehumanize the realities left out by the hard science."18

Epstein wants a new form of humanities based around three aspects: ${ }^{19}$

1. A new anthropology: looking at the study of humans as a biological species - humans evolving from nature;

2. A new humanities: the study of humans as creators and masters of the cultural, semiotic universe, which will uphold the human measure of things by maintaining the immaterial values as they are revealed and perceived by humans; ${ }^{20}$

3. A new humanology: the study of humans as part of the technosphere - humans evolving into artificial forms of life and intelligence, a discipline that studies the (self-)transformation of humans in an advanced technological society.

15 Epstein, The Transformative Humanities, 283. Similar views are found in the multi-authored Digital Humanities Manifesto 2.0. See Presener, ed., Digital Humanities Manifesto 2.0.

16 Berry, "Introduction,” 3, 8; Borgman, “The Digital Future is Now: A Call to Action for the Humanities,” 1; Evans and Rees, "An Interpretation of Digital Humanities," 23-24, 29-30; Hayles, How we think: Digital Media and Contemporary Technogenesis, 25-27.

17 Anderson, "Digital Humanities and the Future of Theology," 1.

18 Epstein, Transformative Humanities, 287-288, 293-294.

19 Ibid., 138-140.

20 Compare this to Liu, "The Meaning," 410: "the Digital Humanities also have a symbolic role. In both their promise and their threat, the Digital Humanities serve as a shadow play for a future form of the humanities that wishes to include what contemporary society values about the digital without losing its soul to other domains of knowledge work that have gone digital to stake their claim to that society.” 
These changes, then, are not so much about "leftist" entryism as Fish suggests but rather the effect of a changing world, a changing context, the prevalence and omnipresence of digitality. It is an acknowledgement that the advanced technological culture in which we now live has had a profound effect on everything we do:

\begin{abstract}
This is what we are witnessing in the Humanities; digital technology will change the way that some of us work, research, and produce material. It will likely also change the conclusions we draw from our work, because of the changes in the conditions of the world brought about by the presence of technology. Technology has always done this and will do so more in the future. The Humanities are about the world, and the research in this volume reflects as much the changes in the world as it does the changes in the research practices and thinking that embrace what we consider to be the Humanities today. ${ }^{21}$
\end{abstract}

But it is also an acknowledgement that digital engagement offers huge potential for extending research and knowledge, for moving beyond the limitations of individual frail humans working alone in ivory towers. For example, Borgman and Hayles have explored the potential of Digital Humanities to move modes of research into newer, deeper, more enhanced forms through distant- or hyper-reading, databases, multimodal scholarship, the creation of humanities laboratories - all pointing to a change in the very way that we think through digital media and contemporary technogenesis. As Berry notes, "medial changes produce epistemic changes."22

\title{
3 Digital Humanities and Digital Theology
}

So far, those changes have not really impacted the once-called "Queen of the Sciences": Theology. Clifford Anderson notes that theologians remain at the margins of the Digital Humanities: "My suspicion is that theological scholars may appreciate what their colleagues in other disciplines are doing but see them as irrelevant to theological enquiry."23

Anderson argues that theologians fail to make use of the methods and tools of Computational Humanities or Digital Humanities. This might be the case among the dusty halls of ancient departments, but there is an increasingly large group of exceptions to this rule including computer-enhanced research among theologians who also engage in ethnography, sociology, text linguistics, semiotics, manuscript studies, and so on. Moreover, very few contemporary theologians are actually ignorant of digital technology, computing, or social media. Contemporary theological scholars are making use of digital resources to do their research; contemporary theological scholarship is as digital as other forms of scholarship in terms of writing, publishing, and dissemination of research. Biblical scholarship was at the forefront of Digital Humanities and continues to make use of the latest developments in computational research. ${ }^{24}$ Theologians do indeed make the most of digital communication. Religious practitioners do make frequent use of presentation software and social networking in their everyday work. ${ }^{25}$ Theologians are as much a part of/immersed in digital culture as others are.

However, there is still confusion around the concept of what is meant by Digital Theology. This confusion is somewhat surprising, especially since Digital Religion has had the benefit of a number of excellent books exploring the field. ${ }^{26}$ Digital Religion has been developed over time and a network of scholars have been active in research and publication. Moreover, this means that aspects of Digital Religion can be re-assessed over time. For example, any researcher within the field knows the distinction developed by Christopher Helland between "online religion (where the religious activity actually occurred in the online environment)

21 Ibid.

22 Berry, "Introduction," 4.

23 Anderson, "Digital Humanities."

24 From almost 30 years ago, even "popular” magazines saw the trend; e.g. Wheeler, "Push-button Bibles: How to Compare Computer Software for Bible Research."

25 Oord, ed., Theologians and Philosophers Using Social Media: Advice, Tips and Testimonials.

26 Cheong et al., eds., Digital Religion, Social Media and Culture; Campbell, ed., Digital Religion: Understanding Religious Practice in New Media Worlds. 
and religion online (where the medium was used as a tool to facilitate religious activity in the 'offline' world)."27

Heidi Campbell explores the history of Digital Religion research which led to Helland's differentiation. ${ }^{28}$ Campbell points out that religion online was seen as the ability of religious organisations to bypass some of the limitations of offline religion, of offline location and offline authority, by providing online resources for adherents of different religions: "Online religion represented how the fluid and flexible nature of the Internet allowed new forms of religiosity and lived religious practices online." 29 The former represents offline practice advertised or facilitated online; the latter describes religious practice online. Helland and others problematised the difference between the two, although Campbell argues, surprisingly, in Networked Religion that the latter is not represented by the concept of Digital Religion. Of course, as with the critique of ritual scholars analyzing religious practices (e.g., worship), it can be difficult to categorize religious communities into one or the other. In fact, the ubiquity of digital means of being in existing and nascent religious communities may allow for both an extension of physical religiosity and the emergence of digital religiosity simultaneously.

Helland's initial theory related to both the mode and content of religious material online. He argued that religion online tended to make use of one-to-many communication, that is advertising offline religious practices to users of the internet, something similar to Web1.0 technology. Online religion, however, makes use of the interactivity of Web2.0 to allow greater user engagement with resources online and so promotes a move from one-to-many to many-to-many communication, collaboration, and co-construction. Interpersonal engagement marks out the development of online religion where people are able to engage in religious practice together online rather than simply being told where they might meet offline: the move from a digital noticeboard to a chat interface/bulletin board, perhaps; or the move from digital passivity to digital interactivity; from Web 1.0 to Web 2.0 to Web 3.0 and the Internet of Things.

However, Digital Religion has itself been through different waves of development. In the excellent edited collection on Digital Methodologies in the Sociology of Religion, Heidi Campbell and Brian Altenhofen outline four waves of digital research development in theology and religion. ${ }^{30}$

- Wave 1: The descriptive wave include early attempts to document the early importance of internet-based religious networking, ritual, and community development and work focused especially on case study analysis and digital ethnography. But also there is a focus on developing a vocabulary and accepted rationale for studying the internet phenomenon.

- Wave 2: The categorical is defined by the development of categories, taxonomies, and labels by which we might group the wealth of online activity; an increase in comparative analysis of different case studies; a recognition of the difference between "religion online" and "online religion" and the shift from Web 1.0 to Web 2.0 and then Web 3.0. Therefore, as discussed above, we note the shift toward religion online as offline religion now present on the internet in a kind of Web 1.0 replication of the offline world (talk of the internet as a high street with addresses; replication of paper resources through PDFs; advertisements of offline opportunities); and then religious experience and practice which is performed online, such as (Web 2.0) activities like cyberchurches (St Pixels, St Marks Cathedral in Second Life, and the plethora of other sacred sites which were popping up all over the place).

- Wave 3: The theoretical is characterized by a turn towards theoretical and interpretative enquiry, looking for methods and tools for analyzing all the data that was being developed out of the research. How do we make sense of all this data? But such shifts allowed scholars to lift their eyes above the details to see how digital culture was affecting all religions and just about every aspect of contemporary social life. In other words, theory helps us to see the global impact of digitality rather than assume it has a micro-affect only on our research. What is happening globally becomes a more dominant trend.

\footnotetext{
27 Helland, “Scholar's Top 5: Christopher Helland on Online Religion and Religion Online.”

28 Campbell, Digital Religion, 2-5.

29 Ibid., 3.

30 Campbell and Altenhofen, "Methodological Challenges," 1-13.
} 
- Wave 4: The convergent wave is where all three of the previous waves that "have emerged and matured over time" coalesce into richer research which brings different aspects together. This wave seeks to ask those deeper questions about society and culture which were emerging at the end of Wave 3: what is the role of institutions and online practices and what of ordinary religion whether it is online or offline? What of hybridity and the frequent merger of offline and online religion within the same experience or ritual.

The waves described by Campbell and Altenhofen are profoundly sociological, as expected both from their own work but also from the publication for which the article was written. They are waves of scholarly approaches to the phenomenon of religious practice online rather than waves of technological engagement with religion. Indeed, the introduction of different waves of technology in Wave 2 (Web 1.0 and Web 2.0) rather confuse the issue. Their waves argue for a gradual methodological shift in focus from the descriptive to the categorical to the theoretical to the convergent. Indeed, at the end of the chapter, they talk of the waves representing a short history of Digital Religion scholarship.

The four waves represent a mix of chronological waves and methodological waves, a kind of ripple affect which points to how a field develops or perhaps even how individual research develops. Campbell's work is clearly located within Waves 3 and 4. It is a mature and internationally important corpus of work, providing robust engagement with Digital Religion from a sociological perspective. Campbell's latest work on Networked Religion looks set to become a set text for future research in the area. ${ }^{31}$

But rather than provide straightforward history, the waves also tend to be typological. They map different approaches to doing research in this field - research which is longitudinal and developmental rather than ephemeral and embryonic. Much of our experience of Digital Religion and Digital Theology, and the literature currently being published in both fields, would argue that each of the waves are still in progress and are not confined to chronological eras. We can see this in the ongoing development of ethnographic research in Digital Religion and Digital Theology. Tim Hutching's book, Creating Church Online, was released in 2016; CODEC's major piece of research on digital millennial engagement with the Bible including polling data from a nationwide survey in the UK was published in March 2019; and Barna has done much the same work in the US..$^{32}$ Ethnographic research was not confined to the late twentieth century (Wave 1) but continues apace today. Indeed, there are now major new explorations of ethnography for the internet and Digital Ethnography which offer new methodologies and practices for contemporary ethnography of digital religion. ${ }^{33}$

Interestingly, Digital Humanities, as we have already suggested above, has also been classified through a kind of wave theory: a pre-wave and three proper waves: ${ }^{34}$

- Pre-Wave: Digitisation/Infrastructure, characterised by the switch from computing in the humanities to the wholesale importing of offline texts into digital formats. This required both a reshaping of institutional approaches to research and the development of new technologies, not least the development of automated reading processes, OCR, and website representation of manuscripts and other texts. How do you visualize that which was once material but is now available in enhanced digital mode?

- Wave 1: Data search, retrieval, collation and automation of analysis, processes that let the computing bear the load.

- Wave 2: Born-Digital Tools/Data Analysis/Distant-Close Reading. Having digitised a good deal of material, Digital Humanities begins to turn to corpus linguistics, analysis of stored libraries and datasets, and the sifting of the mountains of data which are being created within the information revolution.

- Wave 3: Computational Analysis, Coding, and Big Data, AI. What can a computer do that would

31 Campbell and Garner, Networked Theology.

32 Hutchings, Creating Church Online; Ford et al., The Bible and Digital Millennials; Barna, The Bible in America.

33 Hine, Ethnography for the Internet; Pink et al., eds., Digital Ethnography: Principles and Practices.

34 See, for example, Berry, Understanding Digital Humanities; Presner, ed., Digital Humanities Manifesto 2.0. 
be impossible for a human? Distant reading is one answer. But humans are good at things as well, including close reading, interpretation, and human to human communication. So, we develop better and better computers with natural language processing, facial recognition, human interpretation to create a something similar to the "God of the Gaps" argument. We find out what only humans can do and make sure computers do it better. But machine learning can already identify dependencies which cannot be explained by humans doing close reading. For example, the various intertextuality projects finding many thousands more examples of intertextual allusions than humans can make. ${ }^{35}$

Again, these waves are both chronological and methodological. But all waves are now operating at the same time. We are still digitizing materials, we are already working on born digital artefacts, and we are already developing the computational resources to analyse and develop both of the previous waves, we are already engaging with computer-derived data.

Within Digital Theology, still in its infancy in comparison with Digital Humanities, different centres are focusing on different kinds/waves of research. If we were to map them against some of the work being done across a selection of European centres exploring theology and the Digital Humanities or Digital Theology, different institutions focus on different aspects of the Digital Humanities project:

- Scholars at Lausanne, especially Claire Clivaz and Sara Schulthess focus on all things to do with digital manuscripts, especially focusing on the digitization of polyglot manuscripts (wave 1), the development of polyglot OCR (wave 3), and new forms of multimodal education and publishing. ${ }^{36}$

- Scholars at Lugano have explored communication theory and pioneered Digital Pedagogy in association with tourism and lived religion. ${ }^{37}$

- Scholars at Turku and Joenssu, with Erkki Sutinen and Emmanuel Awuni Kolog, focus on technological applications to generate and analyse data for research, on coding and the philosophy of technology (wave 2), on developing VR, AR, and MR representations of Bible stories (wave 3), and, going forward, looking into explorations of sacred space using virtual reality and other media, and perhaps most importantly engaging specifically with the context of the Global South.

- Scholars at the Finnish Bible Society are developing digitalmarkus a prototype digitally-focused translation of the New Testament into Finnish (wave 3). ${ }^{38}$

- A Czech group at the Centre for Philosophy, Theology, and Media Theory at Charles University in Prague focus on the "theological turn" in European media theory around Bernard Stiegler and Bruno Latour (wave 1).

- CODEC focuses both on the history of digital methods and their application to theological research, but also on the practical implications of digitization and digitality - a form of context theology in which the context is all things digital (wave 2) as well as exploring aspects of computational analysis and its impact both on theological research, human identity, and flourishing (wave 3). We have created digital artefacts and are beginning to explore network analysis, and we remain embedded in ethnographic research of digital culture. In part this is because of the emphases different members of staff have brought with them: Marika Rose on human identity, culture and technology; Josh Mann on the Bible, computing, and Digital Humanities; David Ford on the Bible and its readers; Tim Hutchings on the ethnography of Digital Religion; Karen O'Donnell on Digital Theology; Pete Phillips on the Bible in the Digital Age, contemporary technology, and theological reflections on digitality.

35 See, for example Bamman and Crane, “The Logic and Discovery of Textual Allusion”; Coffee et al., "The Tesserae Project: Intertextual Analysis of Latin Poetry"; Franzini et al., "Using and Evaluating TRACER for an Index Fontium Computatus of the Summa contra Gentiles of Thomas Aquinas.”

36 See, Clivaz, Schulthess, Chasapi, "HumaReC: Continuous Data Publishing in the Humanities"; Clivaz, Schulthess, Sankar, "Editing New Testament Arabic Manuscripts in a TEI-base: Fostering Close Reading in Digital Humanities."

37 De Ascaniis, Mutangala, and Cantoni, "ICTs in the tourism experience at religious heritage sites: a review of the literature and an investigation of pilgrims' experiences at the sanctuary of Loreto (Italy)”; Lin, Cantoni and Murph, "MOOCs in tourism and hospitality: a review.”

38 https://www.digimarkus.fi/raamattu/DMrk/Mark-1 (in Finnish). 
However, these four waves are not enough. CODEC and others associated with the Koli gathering of Digital Theology researchers, recognize the need for a fifth wave in Campbell and Altenhofen's scheme, namely a profoundly theological wave, a need to focus on Digital Theology in its own right.

\section{Digital Theology, some definitions}

But what do we mean by this fifth wave? What do we mean by Digital Theology?

In our own research, we find different aspects of both wave schemes but especially a synthesis of Campbell and Altenhofen's Wave 4 (the convergent) with Berry's Wave 2 (analysis of born digital products). Or rather the counter-balance to both: a theological reassessment of digitality and a digital reassessment of theology.

Theology is, of course, a specific discipline. Theology is not the same as the sociology of religion or information studies, or communication studies. Theology is the critical study of the nature of God, or of God's interaction with the world, or of the world's exploration of the mystery of faith. Theology is about thinking through that connection with the other. As such Digital Theology is distinct from its sister discipline Digital Religion which is much more focused on the exploration of the phenomena of religion in digital culture and their meaning. If you look at the various works on Digital Religion, you can see the focus on those phenomena, as well as the questioning about their impacts on religious expression and so on, as in Campbell and Altenhofen waves. In CODEC's MA teaching, we tend to call this digitally-mediated Christianity.

This is not to say that theologians are not active in Digital Religion, or that Digital Religion is not itself a theological enterprise. But to some extent the purpose is sociological and descriptive whereas the purpose of Digital Theology is theological. The distinction between religious studies and theology has been sharper in the United States than in Europe, where theology is more in the purview of seminaries and religiouslyaffiliated institution while religious studies has been dominant in the public university. This split parallels the sacred/secular distinction in America. Yet there has been a move to bring theology into the public university in recent years, as seen with the Public Theology project at the University of California Berkeley. ${ }^{39}$ That said, the disciplines of history and theology are located in the humanities, whereas anthropology and ritual studies are located in the social sciences. The proposed differences between Digital Religion and Digital Theology lies within this same area of distinction.

We propose some possible different levels, or waves, of Digital Theology:

\section{DT1: The use of digital technology to communicate or teach theology as a traditional academic subject}

In DT1, digital is the mode through which a specific academic discipline is communicated. For all intents and purposes the academic discipline does not have to have anything to do with digitality. The academic discipline provides the content and digitality provides the mode by which the content is communicated to the learner.

Changes in theological education (seminaries and divinity schools) over the last decade have been a prime example of this, from the residential classroom paradigm (or even correspondence-like distance education) to synchronous and asynchronous online learning. ${ }^{40}$ For example, over half of the schools accredited by the Association of Theological Schools in the United States and Canada have permission to

39 https://news.berkeley.edu/2015/05/11/campus-gets-1-million-grant-to-boost-study-of-religious-issues/. 40 Schiefelbein-Guerrero, "Educational Technology at the GTU and Beyond.” 
offer six or more online courses, although attempts at online spiritual formation is not without its critics. ${ }^{41}$ Whatever the criticisms, DT1 opens up new possibilities for digital inclusion in theological study, as well as providing a useful and economical mode of delivering such study in the developing world, opening up further pioneering of Digital Theology in a context which lacks the legacy inertia of the Global North. The use of digital platforms to deliver theological education can help us take teaching to harder to reach groups, potentially enabling some of the more prophetic elements of Digital Theology (see below, DT4).

\section{DT2: Theological research enabled by digitality or digital culture}

In DT2, we pick up the idea of Terras and Alan Liu, among others, that digitality changes the whole way in which we do research. Theology is no longer something which we need to do alone in a room surrounded by books. Theological research now includes the analysis of (big) data, distant reading of multiple texts, online religious practice, and the visualization of data.

As an extension of DT1 where the digital environment is used to teach and learn theological disciplines, DT2also utilizes this environment to provide cross-disciplinary or interdisciplinary theological collaboration. For example, Antony-Paul Cooper has demonstrated how to merge together traditional research methodologies with innovative use of social media to identify new churches. In turn, that identification mechanism can then be used to conduct further research such as offline surveys. ${ }^{42}$ Theologians and religious practitioners are no longer restricted by geographical or scholastic distance to analyze, evaluate, and construct theological reflection.

For practical theologians, the plethora of material online has provided more accessible sources for theological analysis. Scholars of preaching and worship can readily access videos of sermons and liturgies..$^{43}$ American copyright law has also allowed more texts to enter the public domain and be digitized without penalty. YouVersion, as the most successful of the Bible apps, provides a wealth of opportunities to study the Bible and to inculcate evangelical Bible reading patterns among the digitally engaged. The data available for researchers in the digital age is simply unprecedented.

However, it is precisely this wealth of online information, instantaneously available and accessible, that leads Peter Horsfield to prophesy that new media will lead to the demise of the academic theologian. Ever since the early church's drive towards amassing its teaching into writings, theology has been the privilege of the elite and literate housed by or backed by powerful institutions like the church. The internet, Horsfield argues, undermines this power asymmetry for it changes how theology is reproduced and disseminated. It is no longer possible for authoritative institutions to control theological reproduction. The internet is democratizing information.

The truism that new media challenges the authority of traditional institutions, as discussed in most books on Digital Religion, needs to be tempered however. After all, while anyone can publish their theological musings from anywhere, it is still predominantly those with resources and institutional backing that will be heard. Peer reviewed monographs and articles are still privileged over blogs and podcasts. Nevertheless, digital culture suggests that the loci of theology are shifting, and this impels theologians to communicate in new ways to new audiences. As Horsfield suggests, in the cyberworld theologians have to compete alongside myriads of voices "by being noticed, easily accessed, and by being attractive...by [their] aesthetic appeal, imagination, humour and practical relevance” or they risk becoming irrelevant. ${ }^{44}$

41 Delamarter, “Theological Educators and their Concerns about Technology”; Kennel, “Technology in the Life of Faith: A call for critical engagement”; Forrest and Lamport, "Modeling Spiritual Formation from a Distance: Paul's Formation Transactions with the Roman Christians”; Hockridge, “'What's the Problem?' Spiritual Formation in Distance and Online Theological Education"; Lowe and Lowe, "Spiritual Formation in Theological Distance Education: An Ecosystems Model”; O’Donnell, "Being Corporeal in Digital Spaces."

42 Cooper and Goodhew, “'Resacralising' Secular Space: New Churches in a Northern City, 1980-2012”; Cooper, "Assessing the Possible Relationship between the Sentiment of Church-related Tweets and Church Growth.”

43 Of course, usually the "best" performances are highlighted on YouTube and other media platforms, which can prevent an observer from getting an accurate view of the community. Grimes, Rite out of Place: Ritual, Media, and the Arts, 23.

44 Horsfield, “'Moderate Diversity of Books?’ The Challenge of New Media to the Practice of Christian Theology,”257. Horsfield, From Jesus to the Internet: A History of Christianity and Media. 


\section{DT3: Intentional, sustained and reflexive theologically-resourced engagement with digitality/digital culture}

In DT3, we see digital culture as the context within which we do theology. This places theology and Digital Culture into a reflexive relationship with each other. Such Digital Theology impacts both theology as a discipline and digital culture as the milieu within which we live. As noted above, Horsfield makes clear that the traditional loci of theology are changing. But does digital change the traditional loci of systematic theology or the various "-ologies" in academic theological study (Christology, theological anthropology, ecclesiology, etc.)? Moreover, how does theology (our reflection on God) impact our understanding of and practice within digital culture? Such questions need to be reflexive. The relationship between theology and digital culture works bi-directionally: theology as the lens through which to analyze digital culture and digital culture as the lens through which to analyze theology; theology as guiding principles with which to participate in digital culture and digital culture offering guiding principles by which we participate in theology.

DT3 - this reflexive contextual interaction between culture and theology - is where CODEC aims to be: to intentionally explore the impact of digital culture on our theology and our theological concepts and, at the same time, intentionally explore the impact of our theology on our digitality. Potentially DT3 provides the place where Anderson's key question might begin to be addressed: "how does Digital Humanities promise to alter the way we read, write, even compute Theology?" 45

Digital Theology is about bringing digital culture and theology together at high speed with colleagues from different disciplines (theologians, scientists, artists, coders, computer scientists, sociologists, entrepreneurs, digital humanists, designers) to see what happens, like a theological large hadron collider. Digital Theology is about interrogating classical religious doctrines and determining how they apply within or are changed by contemporary digital culture, perhaps a form of contextual theology or perhaps constructive theology of some kind since theology always has to speak in the language of its contemporary culture. What do we mean by eschatology in a world of climate change and the Singularity? Will an AI independent of human control perceive a need for forgiveness or salvation? To some extent, Digital Theology reflects Epstein's concept of a "new humanology" that studies how humans have transformed in the technological age. Digital Theology expands Epstein's initial aspect by going beyond anthropological or sociological analysis to theological analysis.

Digital Theology is about exploring what happens when digital tools or methods are applied to theology or theological tools to digital. Can we do online everything that we do offline: online sacraments, a digital haj, communion with the other, pastoral care that transcends geographical and religious boundaries? The latter has been investigated by Kyle K. Schiefelbein-Guerrero from Graduate Theological Union. ${ }^{46}$ Digital Theology is about asking how human beings might flourish within digital culture and about countering online human deficit disorder. How do humans sympathetically adapt to the opportunities and threats digitality presents? Is there a moral or ethical dimension to that digitality? How do isolation, community, narcissism, and personalization change in and because of the digital environment?

\section{DT4: A prophetic re-appraisal of digitality in the light of theological ethics}

This leads us to the final aspect of Digital Theology: the theological-ethical critique of digitality. As an extension of DT3, DT4 appraises the impact of technology on society at large drawing upon the theological toolkit of scripture and tradition. Media is beset with headlines of the impact of digital technology on human well-being, society and politics. Even within the tech industry disquieted voices about the effects of their own creations can be heard. For instance, in a recent article, Hans Vestberg, the CEO of Verizon Communications, made the observation that "for technology to deliver on its promise of human betterment, it needs a cultural and moral compass." ${ }^{47}$

In such a context there are opportunities for theological ethical engagement beyond the disciplinary compounds of theology departments and seminaries. It would be presumptuous to suggest that theologians

45 Anderson, "Digital Humanities.”

46 Schiefelbein-Guerrero, "Neighbor-Care in the Social Network: Rethinking Pastoral Care for the Digital Age."

47 Vestberg, "Why we need both science and humanities for a Fourth Industrial Revolution education." See also https://www. nytimes.com/2017/12/04/technology/silicon-valley-esalen-institute.html. 
could provide totalising solutions to such challenges or indeed that they have a monopoly on such moral and ethical reasoning. Nevertheless, there are at the very least openings to participate in these important public conversations about the underlying ethics, religious assumptions, and telos of technology.

Some important work in this area has already been undertaken, not least among social commentary on the development of digital culture and classical scholars such as Jacques Ellul's dystopian reading of the ubiquity of technology in modern society. ${ }^{48}$ More recently, theologians have been engaged in (digital) media ethics. For example, an edited volume due to be published 2019 brings together various theological perspectives on new media. ${ }^{49}$ Another key area of focus for theologians concerns the human condition and anthropology which cuts to the core of ethical and political questions posed by present and future innovation..$^{50}$ As mirrored in other disciplines, $\mathrm{AI}$ is on the horizon of an increasing number of theologians' agendas and the number of publications in this area is likely to surge in the coming years. ${ }^{51}$ Finally, Eric Stoddart's work on surveillance cultures falls within another area of increasing salience in a data driven digital economy and considering the security threat posed by global terrorism. ${ }^{52}$

Given the pace of technological innovation and the far-reaching implications of digitality on all aspects of human existence, the demand for prophetic appraisals of digital culture cannot be ignored.

\section{Conclusion}

This article has tried to provide some of the foundational theory to the development of Digital Theology as a field of academic pursuit. It has outlined the history of the CODEC research centre at Durham University and how this work has reflected an early experiment in incorporating "big tent" Digital Humanities into theology. Increasing engagement between theology and the Digital Humanities has resulted in the director of CODEC chairing a number of panels at leading international conferences and being invited to give a panel presentation at the leading DH international conference in 2017. It is, perhaps, no longer such a strange thing to see Digital Theology as a theme within grant applications and academic discourse. Moreover, as we have demonstrated throughout this article, academic publications are already published that outline different aspects of Digital Theology.

Digital Theology is still focusing its identity. This is perhaps to be expected in such a nascent field - a teenager striving to determine who she will be in the world and how she will differentiate herself from the masses. But at the same time, Digital Theology reflects many of the issues found in Digital Humanities as a whole and in particular around the concept of "big tent" Digital Humanities. But that is not a problematic lack of focus. Rather it is a signal of how much work is yet to be done.

As such, perhaps we need to add a fifth wave to Campbell and Altenhofen's list to define the role of DT3 in Digital Religion research.

Wave 5 Digital Theology aims:

- to use digital technology to enhance every aspect of the study of theology and religious belief and practice;

- to analyse and critique the use of digital technology within the study of theology and religious belief and practice;

- to describe and contextualise the impact of digital culture upon religious belief and practice;

- to determine digital trends in theology, specifically in terms of religious belief and practice;

- to work through multi-disciplinary research and with scholars from different disciplines;

48 Ellul, The Technological Society; Ellul and Troude-Chastenet, Jacques Ellul on Politics, Technology, and Christianity: Conversations with Patrick Troude-Chastenet.

49 Ulshofer and Wilhelm, eds., Theologische Medienethik im digitalen Zeitalter. See for example, Mitchell and Kurlberg, "Building Peace in View of Digital Violence and Suffering," which proposes a Christian ethical response to the images of violence that flood new media. See also Ess, Digital Media Ethics.

50 Midson, Cyborg Theology; Waters, From Human to Posthuman.

51 Herzfeld, In Our Image: Artificial Intelligence and the Human Spirit is an early exploration of this issue.

52 Stoddart, The Common Gaze: Surveillance and the Common Good. 
- to offer a prophetic reappraisal of digitality in the light of theological ethics;

- to challenge computer scientists to design digital representations for conveying faith-oriented data.

\section{References}

Anderson, Clifford. "Digital Humanities and the Future of Theology.” Cursor: Zeitschrift für explorative Theologie 1 (2018); https://cursor.pubpub.org/pub/anderson-digitalhumanities-2018 [accessed: 10.04.2019].

Bamman, David and Gregory Crane. "The Logic and Discovery of Textual Allusion.” Semantic Scholar [web article] url: https:// www.semanticscholar.org/paper/The-Logic-and-Discovery-of-Textual-Allusion-Bamman/491f4b49c0a0c005d769b0d122 19fbea5424ea56 [accessed: 28.03.2019].

Berry, David. “Introduction: Understanding the Digital Humanities.” In Understanding Digital Humanities, edited by David Berry, 1-20. Basingstoke: Palgrave Macmillan, 2012.

Borgman, Christine. “The Digital Future is Now: A Call to Action for the Humanities.” Digital Humanities Quarterly 3.4 (2009) [web article] url: http://www.digitalhumanities.org/dhq/vol/3/4/000077/000077.html [accessed: 28.03.2019].

Campbell, Heidi, ed. Digital Religion: Understanding Religious Practice in New Media Worlds. London: Routledge, 2013.

Campbell, Heidi and Brian Altenhofen. "Methodological Challenges, Innovations and Growing Pains in Digital Religion Research.” In Digital Methodologies in the Sociology of Religion, edited by Sariya Cheruvallil-Contractor and Suha Shakkour, 1-13. London: Bloomsbury, 2015.

Campbell, Heidi and Stephen Garner. Networked Theology: Negotiating Faith in Digital Culture. Grand Rapids: Baker, 2016. Cheong, Pauline Hope, Peter Fischer-Nielsen, Stefan Gelfgren, and Charles Ess, eds. Digital Religion, Social Media and Culture. New York: Peter Lang, 2012.

Cheruvallil-Contractor, Sariya and Suha Shakkour. Digital Methodologies in the Sociology of Religion. London: Bloomsbury, 2015.

Clivaz, Claire, Sara Schulthess, and Anastasia Chasapi. "HumaReC: Continuous Data Publishing in the Humanities.” ERCIM News 11, 2017, 21-22 url: https://ercim-news.ercim.eu/images/stories/EN111/EN111-web.pdf [accessed: 25.03.2019].

Clivaz, Claire, Sara Schulthess, and Martial Sankar. "Editing New Testament Arabic Manuscripts in a TEl-base: Fostering Close Reading in Digital Humanities." Journal of Data Mining and Digital Humanities, Special Issue on ComputerAided Processing of Intertextuality in Ancient Languages, 2017, 217-235, url: https://jdmdh.episciences.org/paper/ view?id=3700 [accessed: 25.03 .2019 ].

Coffee, Neil, Jean-Pierre Koenig, Shakthi Poornima, Christopher Forstall, Roelant Ossewaarde, and S. Jacobson. "The Tesserae Project: Intertextual Analysis of Latin Poetry." LLC 28 (2011): 221-228.

Cooper, Anthony-Paul. "Assessing the Possible Relationship between the Sentiment of Church-Related Tweets and Church Growth." Studies in Religion/Sciences Religieuses 46 (2017): 37-49.

Cooper, Anthony-Paul and Daivd Goodhew. “'Resacralising' Secular Space: New Churches in a Northern City, 1980-2012.” Journal of Contemporary Religion 32 (2017): 495-511.

De Ascaniis, Silvia, Marc-Marie Mutangala, and Lorenzo Cantoni. "ICTs in the Tourism Experience at Religious Heritage Sites: A Review of the Literature and an Investigation of Pilgrims' Experiences at the Sanctuary of Loreto (Italy)." Church. Communication and Culture 3 (2018): 310-334.

Epstein, Mikhael. The Transformative Humanities. New York: Bloomsbury, 2012.

Ess, Charles. Digital Media Ethics. London: Polity Press, 2009.

Evans, Leighton and Sian Rees. "An Interpretation of Digital Humanities." In Understanding Digital Humanities, edited by David Berry, 21-41. Basingstoke: Palgrave Macmillan, 2012.

Franzini, Greta, Marco Passarotti, Maria Moritz, and Marco Büchler. "Using and Evaluating TRACER for an Index Fontium Computatus of the Summa contra Gentiles of Thomas Aquinas." Semantic Scholar [web article] url: https://www.semanticscholar.org/paper/Using-and-Evaluating-TRACER-for-an-Index-Fontium-of-FranziniPassarotti/4d576231ebf2c12a75cdf9e613dedb6c19980828 [accessed: 28.03.2019].

Fish, Stanley. “The Digital Humanities and the Transcending of Mortality.” http://opinionator.blogs.nytimes.com/2012/01/09/ the-digital-humanities-and-the-transcending-of-mortality/ [accessed: 25.03.2019].

Ford, David, Joshua Mann, and Peter Phillips. The Bible and Digital Millennials. London: Routledge, 2019.

Forrest, Benjamin and Mark Lamport. "Modeling Spiritual Formation from a Distance: Paul's Formation Transactions with the Roman Christians." Christian Education Journal 3 (2013): 110-124.

Grimes, Ronald. Rite out of Place: Ritual, Media, and the Arts. New York: Oxford University Press, 2006.

Ellul, Jacques. The Technological Society. London: Jonathan Cape, 1965.

Ellul, Jacques and Patrick Troude-Chastenet. Jacques Ellul on Politics, Technology, and Christianity: Conversations with Patrick Troude-Chastenet. Eugene: Wipf and Stock, 2005.

Hayles, N. Katherine. How we Think: Digital Media and Contemporary Technogenesis. Chicago: University of Chicago Press, 2012. 
Helland, Christopher. "Scholar's Top 5: Christopher Helland on Online Religion and Religion Online." NNMRDC Blog Series, 2012. https://digitalreligion.tamu.edu/blog/mon-05142012-1132/scholar's-top-5-christopher-helland-online-religionand-religion-online [accessed: 25.03.2019].

Herzfeld, Noreen. In Our Image: Artificial Intelligence and the Human Spirit. Minneapolis: Augsburg Fortress, 2000.

Hine, Christine. Ethnography for the Internet. London: Bloomsbury, 2015.

Hockridge, Diane. “'What's the Problem?' Spiritual Formation in Distance and Online Theological Education.” Journal of Christian Education 54 (2011): 25-38.

Horsfield, Peter. “'Moderate Diversity of Books?' The Challenge of New Media to the Practice of Christian Theology.” In Digital Religion, edited by Cheong, Pauline, Fischer-Nielsen, Peter, Gelfgren, Stefan and Ess, Charles, 243-258. New York: Peter Lang, 2012.

Horsfield, Peter. From Jesus to the Internet: A History of Christianity and Media. Chichester: Wiley Blackwell, 2015.

Hutchings, Timothy. Creating Church Online. London: Routledge, 2016.

Lewis, Bex. Raising Children in the Digital Age. London: Lion Hudson, 2014.

Lin, Jingjing, Lorenzo Cantoni, and Jamie Murphy. “MOOCs in Tourism and Hospitality: A Review." Journal of Teaching in Travel and Tourism 18 (2018): 1-19.

Delamarter, Steve. "Theological Educators and their Concerns about Technology." Teaching Theology and Religion 8 (2005): 131-143.

Kyrre-Friis, Jan and Evan Selinger, and Søren Riis, eds. New Waves in the Philosophy of Technology. New York: Palgrave Macmillan, 2009.

Liu, Alan. “The Meaning of the Digital Humanities.” PMLA 128 (2013): 409-423.

Lowe, Stephen and Mary Lowe. "Spiritual Formation in Theological Distance Education: An Ecosystems Model." Christian Education Journal Series 3 (2011): 85-102.

Mann, Joshua. “The Hermeneutics of Digital Bibles." In From Scrolls to Scrolling: Sacred Texts, Materiality, and Dynamic Media Cultures, edited by Bradford Anderson. Berlin: De Gruyter, forthcoming.

Mann, Joshua. “Augmented Reality, Virtual Reality, and Religion: Past, Present, and Future.” In Believing in Bits: Digital Media and the Supernatural, edited by Natale, Simone and Pasulka, Diana, n.p. Oxford: Oxford University Press, forthcoming.

Mann, Joshua. "Mobile Liturgy: Reflections on the Church of England's Suite of Digital Apps." Online - Heidelberg Journal of Religions on the Internet 12.3 (2017)

Mann, Joshua. “How Technology Means: Texts, History, and Their Associated Technologies.” Digital Humanities Quarterly 12 (2018) [web article] url: http://www.digitalhumanities.org/dhq/vol/12/3/000398/000398.html [accessed: 28.03.2019].

Midson, Scott. Cyborg Theology. London: I.B. Tauris, 2018.

Mitchell, Jolyon and Jonas Kurlberg. "Building Peace in View of Digital Violence and Suffering." In Theologische Medienethik im digitalen Zeitalter, edited by Ulshofer, Gotlind and Wilhelm, Monika, n.p.. Stuttgart: Kohlhammer, forthcoming.

Neville, Robert. "Religious Studies and Theological Studies." Journal of the American Academy of Religion 61 (1993): 185-200.

Nowviskie, Bethany. “On the Origin of 'Hack' and 'Yack.”' http://nowviskie.org/2014/on-the-origin-of-hack-and-yack/ [accessed: 25.03.2019].

O’Donnell, Karen. “Performing the imago Dei: Human Enhancement, Artificial Intelligence and Optative Image-Bearing." International Journal for the Study of the Christian Church 18 (2018): 4-15.

O’Donnell, Karen. "Being Corporeal in Digital Spaces." International Journal of Public Theology, forthcoming.

O’Donnell, Karen and Scott Midson, eds. "Special Edition on Human Relationships and Digital Technologies." Journal of Theology and Sexuality, forthcoming.

O’Donnell, Karen. Digital Theology: Constructing Theology for a Digital Age. London: Bloomsbury, forthcoming.

Ogden, Schubert. “Theology and Religious Studies: Their Difference and the Difference It Makes." Journal of the American Academy of Religion 46 (1978): 3-17.

Oord, Thomas, ed. Theologians and Philosophers Using Social Media: Advice, Tips and Testimonials. San Diego: SacraSage, 2017.

Phillips, Peter. “A Responsive Chorus: The Samaritans of Sychar.” In Character Studies in the Fourth Gospel, edited by Cor Bennema, 292-298. Tübingen: Mohr Siebeck, 2013.

Phillips, Peter. “The Adulterous Woman: Nameless, Partnerless, Defenceless.” In Character Studies in the Fourth Gospel, edited by Cor Bennema, 407-420. Tübingen: Mohr Siebeck, 2013.

Phillips, Peter. “Security and Privacy in a Digital Age.” [web article] url: https://www.academia.edu/38760846/Security_and_ Privacy_in_a_Digital_Age_A_Response_to_M34_2013 [accessed: 28.03.2019].

Phillips, Peter. “Wesley's Parish and the Digital Age.” Holiness 2 (2016): 337-358.

Phillips, Peter. Engaging the Word: The Bible and Discipleship. Swindon: BRF, 2017.

Phillips, Peter. “The Pixelated Text: Reading the Bible within Digital Culture.” Theology 121 (2018): 403-412.

Phillips, Peter. "The Power of Visual Culture and the Fragility of the Text." In Ancient Manuscripts in Digital Culture: Visualisation, Data Mining, Communication, edited David Hamidović, Claire Clivaz, and Sarah Bowen-Savant. Leiden: Brill, forthcoming. 
Phillips, Peter, Bex Lewis and Kate Bruce. “Digital Communication, the Church and Mission.” [web article] url: http://www.churchgrowthrd.org.uk/UserFiles/File/Resourcing_Mission_Bulletin/June_2013/Digital_ Communication_the_Church_and_Mission.pdf [accessed: 28.03.2019].

Phillips, Peter and Richard Briggs. "The Bible as Augmented Reality.” Theology and Ministry Journal 1 (2013), url: http://www.dur.ac.uk/resources/theologyandministry/TheologyandMinistry1_2.pdf [accessed: 28.03.2019].

Pink, Sarah, Heather Horst, John Postill, Larissa Hjorth, Tania Lewis, and Jo Tacchi, eds. Digital Ethnography: Principles and Practices. London: Sage, 2015.

Presner, Tom, ed. Digital Humanities Manifesto 2.0. http://www.humanitiesblast.com/manifesto/Manifesto_V2.pdf [accessed: 25.03.2019].

Rose, Marika. “Machines of Loving Grace: Angels, Cyborgs, and Postsecular Labour.” Journal for Cultural and Religious Theory 16 (2017): 240-259.

Rose, Marika. “'It's Not the Money but the Love of Money That Is the Root of All Evil.” Religions 7 (2016): 1-12.

Schiefelbein-Guerrero, Kyle, "Educational Technology at the GTU and Beyond." Currents (2016): 13-15.

Schiefelbein-Guerrero, Kyle. “Neighbor-Care in the Social Network: Rethinking Pastoral Care for the Digital Age.” Paper presented at the Ecclesial Practices Unit of the American Academy of Religion, Denver, CO, November 2018.

Stommel, Jesse, "Digital Humanities is about Breaking Stuff." http://hybridpedagogy.org/the-digital-humanities-is-aboutbreaking-stuff/ [accessed: 25.03.2019].

Stoddart, Eric. The Common Gaze: Surveillance and the Common Good. London: SCM Press, 2019.

Terras, Melissa. “Peering Inside the Big Tent." In Defining Digital Humanities, edited by Melissa Terras, Julianne Nyhan, and Edward Vanhoutte, 263-270. Defining Digital Humanities. Farnham: Ashgate, 2013.

Thomson, lain. "Understanding Technology Ontotheologically." In New Waves in the Philosophy of Technology, edited by Jan Kyrre-Friis, Evan Selinger, and Søren Riis, 149-166. New York: Palgrave Macmillan, 2009.

Ulshofer, Gotlind and Monika Wilhelm, eds. Theologische Medienethik im digitalen Zeitalter. Stuttgart: Kohlhammer, forthcoming.

Vestberg, Hans. "Why we Need both Science and Humanities for a Fourth Industrial Revolution Education." World Economic Forum. https://www.weforum.org/agenda/2018/09/why-we-need-both-science-and-humanities-for-a-fourth-industrialrevolution-education/ [accessed: 25.03.2019].

Vestberg, Hans, "Silicon Valley Esalen Institute.” NY Times https://www.nytimes.com/2017/12/04/technology/silicon-valleyesalen-institute.html [accessed: 25.03.2019].

Warwick, Claire, Simon Mahoney, Julianne Nyhan, and Claire Bailey Ross. "UCLDH: Big Tent Digital Humanities in Practice." Digital Humanities 2011 Conference Abstracts, 387-389. Standford: Standford University Library.

Waters, Brent. From Human to Posthuman. Aldershot: Ashgate, 2006.

Wheeler, Dale. "Push-button Bibles: How to Compare Computer Software for Bible Research.” Christianity Today 34 (1990): 3-13. 